TITLE:

\title{
The Potential of Fijian Traditional Housing to Cope with Natural Disasters in Rural Fiji
}

$\operatorname{AUTHOR}(\mathrm{S})$ :

Fujieda, Ayako; Kobayashi, Hirohide

\section{CITATION:}

Fujieda, Ayako ...[et al]. The Potential of Fijian Traditional Housing to Cope with Natural Disasters in Rural Fiji. Journal of Disaster Research 2013, 8(1): 18-27

ISSUE DATE:

2013-02

URL:

http://hdl.handle.net/2433/173637

\section{RIGHT:}

(C) 2013 Fuji Technology Press Co, . Ltd.; この論文は出版社版でありま せん。引用の際には出版社版をご確認ご利用ください。; This is not the published version. Please cite only the published version. 


\title{
The Potential of Fijian Traditional Housing to Cope with Natural Disasters in Rural Fiji
}

\author{
Ayako Fujieda and Hirohide Kobayashi \\ Graduate School of Global Environmental Studies, Kyoto University \\ Yoshida Honmachi, Sakyo-ku, Kyoto 606-8501, Japan \\ E-mail: \{fujieda.ayako.8r@, kobahiro@archi.\}kyoto-u.ac.jp \\ [Received October 10, 2012; accepted January 21, 2013]
}

\begin{abstract}
Fiji is, as an island country in the Pacific Ocean widely recognized to be vulnerable to natural disasters due to its location and characteristics. Recent studies show the increasing emphasis on a capacity of disaster affected people and communities rather than their vulnerability and on what they can do for themselves. In the light of resilience, indigenous knowledge that has been generated and accumulated over years in adapting to the local environment has the potential to enhance the capacity of the local people to cope with natural disasters. Despite the increasing recognition of the advantages of such indigenous knowledge, its potential use in present day is little known. This paper explores the potential use of Fijian traditional housing as an alternative in restoring the living environment in rural Fiji where housing reconstruction depends heavily on the external assistance. Field study was carried out to understand current conditions and the potential of traditional housing construction in the modern context. Although traditional housings hardly exists in Fiji, field study results show the availability of natural resources, skills and knowledge, communal work and challenges in knowledge transfer and challenges brought by the life-style changes.
\end{abstract}

Keywords: Fijian traditional housing, coping capacity, indigenous knowledge cyclone, Fiji, Pacific islands

\section{Introduction}

Fiji is as a Pacific island, is widely recognized to be vulnerable to natural hazards due to its location and characteristics as a small island state. In addition to frequent exposure to the meteorological and geological hazards, such island states they are likely to be adversely affected by the impact of climate change [1]. Their smallness and geographical isolation as the special disadvantages of small island states contribute to their vulnerability to the natural hazards. Moreover, contemporary global changes and local dynamic pressure play a key role in shaping local vulnerability [2].

Over the past ten years, some researchers and practitioners have shifted their focus more from the vulnerability to the capacity of affected communities, i.e., what they can do for themselves with little or no external assistance [3]. Over the hundreds of years, prior to European contact the Pacific communities had survived recurrent natural hazards on their own and their extensive knowledge and experience have molded their lifestyle to cope with the natural hazards $[4,5]$. In a recent study, Mercer emphasizes on the potential of the indigenous knowledge for the disaster risk reduction in the small island states [6].

The Republic of Fiji (Fiji) is one of the Melanesian countries located in the South Pacific. It is prone to various natural hazards, including cyclones that are considered the most hazardous kinds of disaster in terms of frequency and damage. Cyclones cause extensive damage, especially to housing, and the provision of temporary housing and the support of reconstruction are major challenges, especially in rural villages, due to their limited access. In order for disaster-affected people to restore their living environment, alternative solutions that do not depend on external assistance need to be explored.

In order to address issues of housing in the face of cyclones, this paper examines the potential of Fijian traditional housing which has developed over years by the local people with their extensive knowledge. This paper begins with a review of the cyclone impacts on housing and identifies the needs for a locally based alternative solution. This leads to the assumption that adaptation of Fijian traditional housing can be one solution. Then the potential of Fijian traditional housing construction are examined based on the field studies. Finally, this paper discusses the future direction to promote the Fijian traditional housings to enhance the capacity of people to cope with cyclones.

\section{Research Background}

\subsection{Focus on Local Capacity}

In the light of failure in development after World War II, researchers and practitioners have recognized the insufficiency of externally introduced initiatives mainly with technological fixes and have begun to emphasize on a participatory and decentralized development. There is a need not only to learn from the local people and respect their realities and priorities [7] but also to facilitate their original development by highlighting their capacity. In the course of a change in perspectives on development, a 
number of reports in the literatures pays attention to indigenous knowledge, and highly detailed and complex information on the local environment, and advocates its applicability, especially in marginal environments [8].

\subsection{Nature of Indigenous Knowledge}

Although there is no single definition of indigenous knowledge, relevant literatures indicate several interrelated aspects which characterize the nature of indigenous knowledge. The indigenous (traditional) knowledge is the body of knowledge that is essential for the survival of the local people [9] and is developed to respond to everyday demands of life [10], adapt to the biophysical environment [11] and to achieve the sustainable livelihood in the physical, economical, and environmental constrains.

Indigenous knowledge is holistic and very complex: generated by local people to adapt to their environment, unique in a given society and context-dependent, dynamic and influenced by internal and external factors, and stored and transferred in traditional ways. Indigenous knowledge reflects the complexity of reality and therefore should be considered to have a potential to provide local solutions. As local people use a particular piece of knowledge only when it makes economic and sociocultural sense to them, it is characterized as pragmatic and utilitarian [12].

\subsection{Overview of Fijian Village}

The Fiji has an area of $18,333 \mathrm{~km}^{2}$ and a population of 837,271 , consists of approximately 330 islands, of which about 110 are inhabited. Two major islands, Viti Levu and Vanua Levu, account for 80 percent of the nation land and have 87 percent of the total population. The rest of the population are scattered in smaller islands. While the urban population continues to increase, a nearly half of the population still lives based on subsistence farming in rural areas [13].

Fiji is a nation made up of diverse races and culture. The traditional housings addressed in this paper are the parts of the culture of the Indigenous Fijians which consists of 56.8 percent of the population. The rest include Indians (37.5 percent), Europeans, Rotumans, and other Pacific islanders. The 87.9 percent of the land is registered by the land owning unit (mataqali / clan) of Indigenous Fijians while the others include State Hold (3.9 percent), Freehold land (7.9 percent) and Rotuman land (0.3 percent) [13].

In Fiji, 'village' refers to koro which based on the Fijian administration while "settlement" refers to place of residence on lease, owned land, or at will apart from villages. In Fijian administration, Fiji is divided into provinces which consists of several tikina (districts). Each tikina is made of several koro or villages. There are 14 provinces, 189 tikinas, and 1171 koro in Fiji.

There is a distinctive social structure in the Fijian villages. The three-fold social division is wildly accepted by both Fijians and by the Government of Fiji for the local government administration in the modern days [14]. The

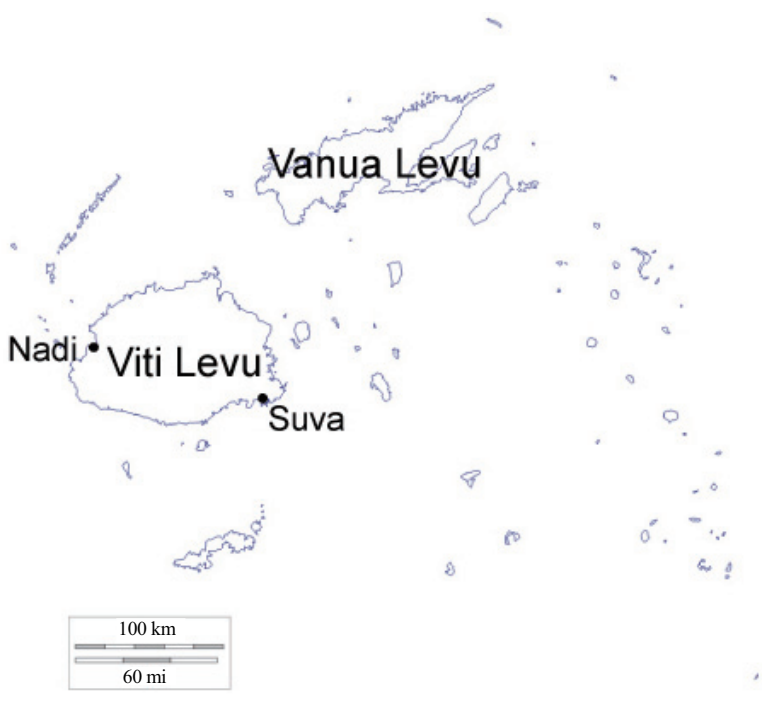

Fig. 1. Map of Fiji.

largest social unit for Fijians is the yavusa (tribe) which reside often in one or a few villages. Yavusa is composed of two or more mataqali (clan) which is generally the land owning unit and has the kin-group origin with traditional roles and functions in yavusa.

\section{Issues with Rural Housings in the Face of Tropical Cyclones}

\subsection{Characteristics of Cyclones}

Tropical cyclones are the most common natural disasters in Fiji. Since 1840, nearly 200 cyclones have been reported. They occurred most frequently between December and April, but the recognized season extends from October to May, taking account of the possibility of early and late events such as Tropical Cyclone Bebe, which heavily impacted entire Fiji in October 1972. Two thirds originated north-west of and the others tend to strike from the north with southern and eastern parts of the island group most likely to be affected. The incidence of cyclones is 1.2 per season but this figure conceals variations from season to season. In 1985, four occurred in four months. They included Tropical Cyclones Eric and Nigel which struck densely populated area. Tropical cyclones develop destructive winds and heavy rains, and have hit Fiji, with some of them causing extensive damage mainly to agriculture, housing, and infrastructures.

\subsection{Cyclone Impacts and Vulnerability of Rural Housing}

The recurrence cyclones have placed an enormous burden on the country and the people. They have caused extensive damages mainly on agriculture, housings, and infrastructures (Table 1). Strong winds developed by tropical cyclones heavily impact on housing (Fig. 2), which is damaged or destroyed by cyclones due to the inadequacy 
Table 1. Summary of major damages by the recent tropical cyclones (TC) (compiled by the author).

\begin{tabular}{lclrrrr}
\hline $\begin{array}{l}\text { TC Name Cost } \\
\text { in FJD }\end{array}$ & $\begin{array}{l}\text { TC Ami } \\
(2003)[26]\end{array}$ & $\begin{array}{l}\text { TC Cliff } \\
(2004)[27]\end{array}$ & $\begin{array}{l}\text { TC Daman, } \\
(2007)[28]\end{array}$ & $\begin{array}{l}\text { TC Gene } \\
(2007)[29]\end{array}$ & $\begin{array}{l}\text { TC Mick } \\
(2009)[30]\end{array}$ & $\begin{array}{l}\text { TC } \\
(2010)[15]\end{array}$ \\
\hline Agriculture & $40,330,619$ & $4,771,343$ & 104,671 & $25,144,394$ & $32,433,606$ & $48,955,695$ \\
\hline Sugar & $13,600,000$ & N/A & N/A & N/A & 367,020 & $3,300,000$ \\
\hline Housing & $\mathbf{2 2 , 0 8 9 , 2 0 0}$ & $\mathbf{7 0 3 , 9 7 4}$ & $\mathbf{2 3 7 , 4 8 5}$ & $\mathbf{5 , 1 8 7 , 6 1 5}$ & $\mathbf{1 9 , 8 9 0 , 5 0 0}$ & $\mathbf{1 0 , 2 0 7 . 0 0 1}$ \\
\hline Infrastructure & $5,792,435$ & $3,386,860$ & N/A & $13,340,000$ & $2,877,302$ & $14,150,787$ \\
\hline Utilities & $4,580,400$ & 27,081 & 8,000 & $6,401,500$ & 971,000 & $1,794,400$ \\
\hline Education & $4,770,635$ & 73,948 & 149,195 & 621,155 & $1,330,915$ & $4,052,517$ \\
\hline Health & 857,000 & 0 & 900 & $1,651,220$ & 130,430 & $1,363,400$ \\
\hline
\end{tabular}
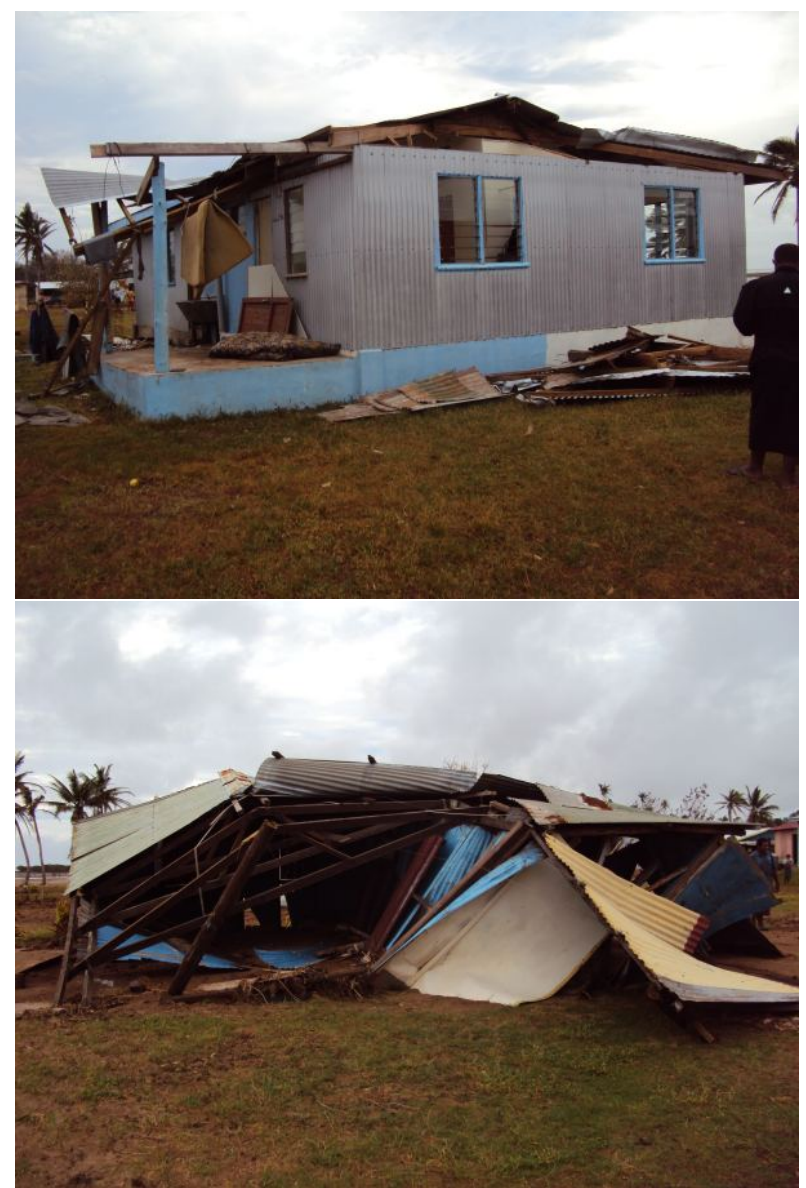

Note) Photos were taken on the Lakeba island in the southern Lau Archipelagon on March 21, 2010 by National Disaster Management Office

Fig. 2. Damaged housings by the Tropical Cyclone Tomas (2010).

of the materials used and/or the structure. The number of damaged and destroyed housing by the Cyclone Tomas traveled from north through eastern Fiji in March 2010 was 1387 and 649 respectively [15].

Housing in Fiji exists in various quality and materials use. They are subject to be damaged or destroyed from the cyclones especially in rural areas. According to the census in 1996 on housing adequacy indicate that the percentages of urban and rural housings falls into su- perior, above average including well-constructed woodframe and concrete-block housings are 27.7 percent and 7.8 percent respectively [16]. In contrast, the percentages of housings categorized into 'below average' and 'inferior' are 36.9 percent for urban and 61.7 percent for rural [16].

This housing is made of corrugated iron roofs and walls from various materials, including corrugated iron, bamboo, local wood, and concrete, and is often poorly constructed due to insufficient knowledge of proper housing construction with these materials. Although most of this housing is somehow in "transitional" status between traditional and modern housing, the limited cash income of people living from subsistence farming in rural areas does not allow them to make many improvements on housing.

\subsection{Challenges in Housing Reconstruction}

The rural housing is subject to damage by the cyclones due to its vulnerability. The provision of shelter and housing reconstruction in timely manner for those whose housing was destroyed is an urgent issue.

According to an assessment conducted after three months from the 2007 Tropical Cyclone Cliff in Saqani, Tawake, and Rabi, 23 households that lost their home had not received assistance for housing reconstruction. 15 of them stayed or had stayed with their relatives; and 10 of them had built temporary shelters with traditional materials and/or salvaged materials by the owner. Such temporary shelters were corrugated clad temporary structure and corrugated iron roof shad with plastic sheet. It is 'uncomfortable to live in, but family tried to cope with the situation until assistant arrived.'

The distribution of tents from the government started in 1970s has not given much solution. It is costly for the establishment of stocks and distribution. Although the affected people are protected for a place for sheltering by such means, they cannot stay long in these shelters and cannot able to resume daily life.

The prompt and accurate assessment of the extent of the damage is the first step for the housing reconstruction program. Though, the post-disaster assessment is particularly difficult especially when the cyclone has affected an extended area or in remote areas. The housing reconstruction program takes time. Although it is usually taken 
place a few months after the cyclone, there will be possible delays due to a number of factors such as the availability of funds, human resources, material supply, transportation, and construction efficiency.

A long history of provision of housings by the government and the external agencies after disasters has discouraged them to reconstruct their housing by their own. They tend to rely on external assistance. However, there is a limitation of the government to respond to all the needs. In addition, it is not promised that the international assistance is given in the same manner. Under the circumstances where limitation in external assistance, people's expectation and their dependence on the assistance have them in the living environment that does not give much comfort and hinder them to resume their daily life with normality.

\subsection{Need for Alternative Solution for Shelter}

There is a time gap that needs to be bridged over between temporary sheltering and housing reconstruction. The government or external agencies' housing reconstruction takes time and create dependency. The Director of National Disaster Management Office (NDMO) noted that there is a need for an alternative solution to ensure adequate living space in timely manner [17]. An alternative way of housing reconstruction needs to be quick and to enhance local people's capacity instead of dependency.

Instead of the provision of housing, the UNCRO's report suggests 'rapid reconstruction' which adapts the selfhelp methods and mobilizes the local resources, human and material, it utilizes the resource for more permanent effect and accelerates full recovery accelerates full recovery [18]. Promoting such way of housing reconstruction will not only accelerate the recovery but also reduce the dependency and enhance capacity of people to recover on their own.

\section{The Potential of Fijian Traditional Housing}

\subsection{Fijian Traditional Housing for Alternative So- lution}

This paper explores on housing reconstruction with self-build methods by utilizing local resources as an alternative solution. Generally speaking, the traditional housing had been shaped over time to satisfy the most of the cultural, physical, and maintenance requirements; it is built by the local people using their intelligence, ability and resources to their fullest extent [19]. This paper assumes that traditional housing has the characteristics of self-build with locally available resources. In this case, it is Fijian traditional housing.

Fijian traditional housing is often referred as 'vale vaka-viti' (Fijian's house) in Fijian or known as 'bure' by the foreigners in present days. It is a one-room thatched house with earthen floor usually covered with $i b i$ (mat). Form and used materials for the construction vary throughout the country [20].
The reconstructed housing should be sustained for the lengthy period of time and provides comfort an alternative solution. Fijian traditional housing is often referred as 'cool inside when it is hot, and warm inside when it is hot' and recognized to suitable for the climate. It is also said that it fits their living style and will give much more comfort than current temporary shelter or tents [17]. Wellconstructed one may last for thirty or forty years [21]. Fijian traditional housing can be considered as housing that ensures comfortable living environment for the duration.

In order for local people to utilize Fijian traditional housing as alternative solution, it needs to analyze whether it can be constructed with locally available resource by local people in timely manner especially in present day.

\subsection{Need for Understanding Fijian Traditional Housing Construction in Present Day}

Fijian traditional housing in villages has been replaced by housing with newly introduced materials and styles in the latter half of the twenty century. The number of Fijian traditional housing had dropped from 9 percent to 3.8 percent from 1986 to 1996 [16]. It assumed that the number is even lesser today The major contribution factors of a decrease in number are European influence and increase in cash brought to villages [14,22]. It is hardly constructed in most villages in present day.

Barakat notes that housing design for self-build needs to be relatively simple [23]. For a wider application, Fijian traditional housing should be constructed with simple technologies by people at large. If it is constructed only by a group of specific skilled carpenters, it cannot be selfbuild. Under present conditions, it also needs to identify whether people with knowledge and skills still exists in villages. Self-build is possible when communities have a tradition of self-building and labor is available [19]. In order for early recovery, time and labor requirements for construction should be considered. In addition to human resources, materials and equipment for construction needs to be available at community. In Fiji's case, it should be at a village level. With the purpose to explore the potential of Fijian traditional housing as an alternative solution for housing recovery, following case study identify physical characteristics and factors need for construction and their availability from knowledge and skills, workforce, equipment and tools and natural resource.

For this purpose, the observation was made during the process of Fijian Traditional Housing Model Construction Project at Centre for Appropriate Technology and Development (CATD). Although construction was carried out outside of village, it was built by a carpenter and local people from a nearby village in a traditional way. Situation may be different from village to village, though observation of actual construction gave an insight into understanding nature of Fijian traditional housing construction and necessary from the standpoint of potential for self-help housing recovery. 

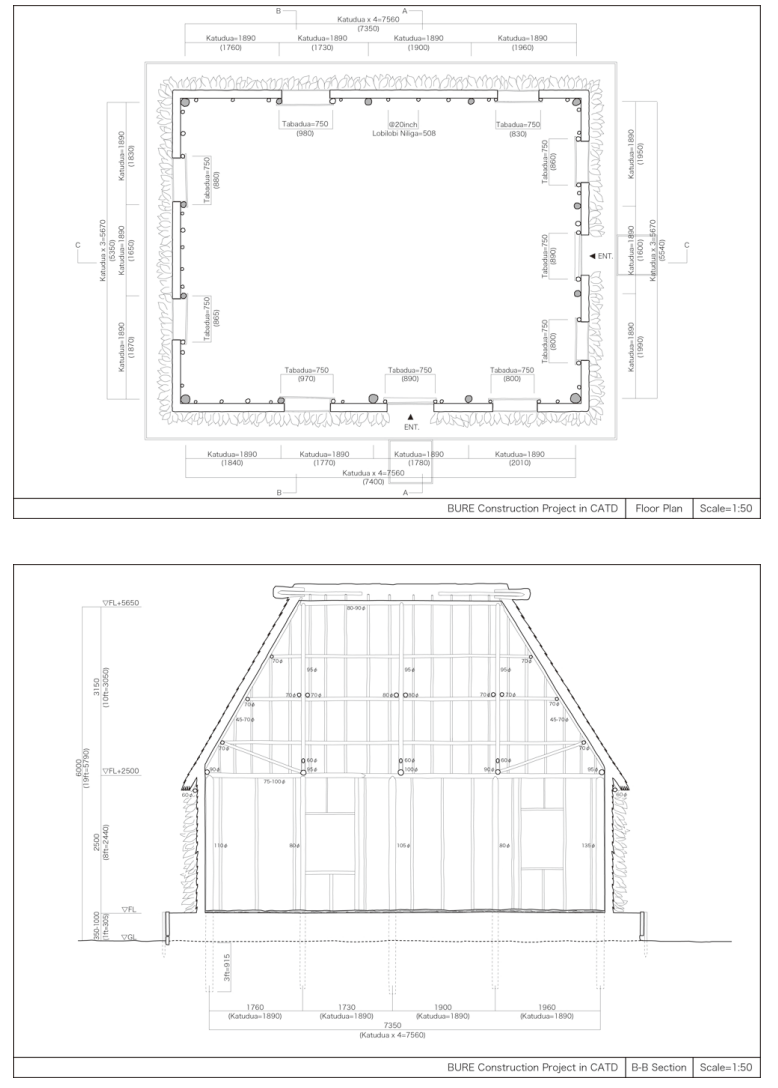
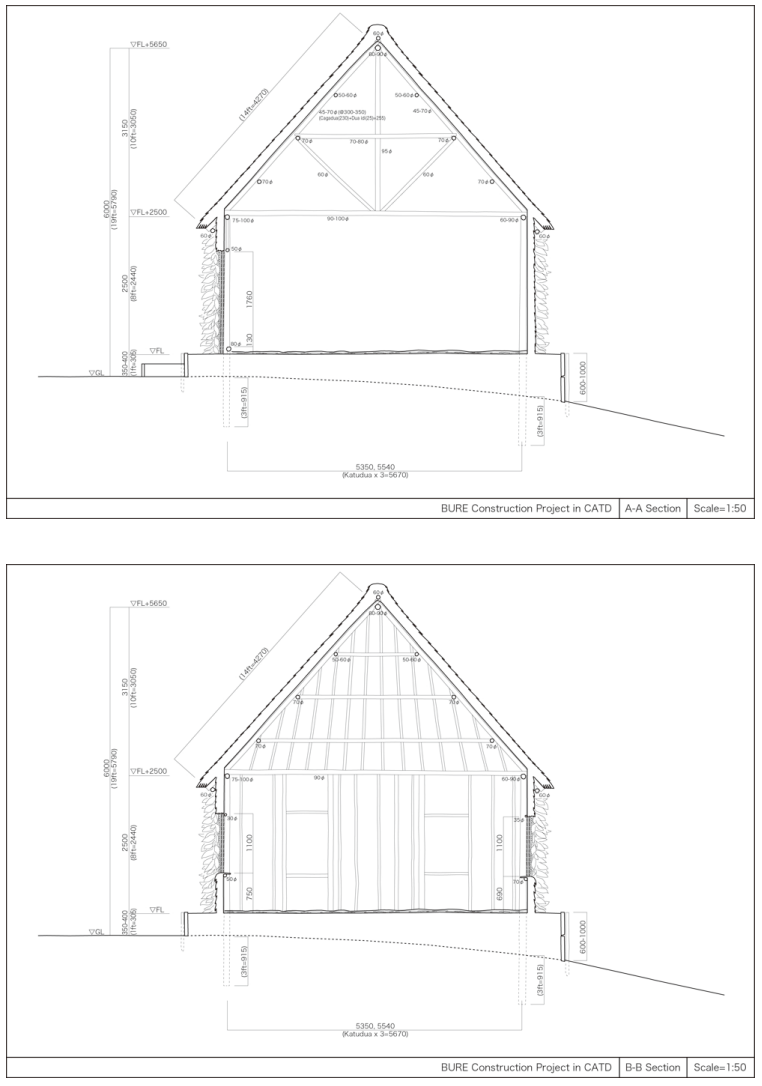

Fig. 3. Forms and size of the constructed Fijian traditional housing.

\section{Fijian Traditional Housing Construction}

\subsection{Fijian Traditional Housing Model Construc- tion Project}

The project was initiated thanks to the willingness of the CATD director to give opportunities to the younger generation to learn about traditional housing. It was a cooperative effort of the CATD, a nearby village called Cautata, and a Kyoto University research team. Preparation started in 2010 and actual material collection and construction were carried out in August and September 2011. It cost 12,300 FJD (roughly JP $¥ 58,725$ ) for material collection and construction labor and transportation cost.

The CATD is a government training institution located in Nadave, about $5 \mathrm{~km}$ northeast of Nausori Town. It provides four one-year technical training courses, including carpentry, to young Fijian males from 18 to 23 years old to improve their livelihood in rural Fiji. Ten students from the carpentry course from the CATD occasionally participated in the building process as a part of their course work.

For the project, a master carpenter was selected from the village of Cautata, $3 \mathrm{~km}$ away from the CATD. The village, which belongs to Tikina Bau in Tailevu Province, is located along a coast with mangrove forests. A master carpenter and eight villagers, including his son, took the main roles in material collection and construction.

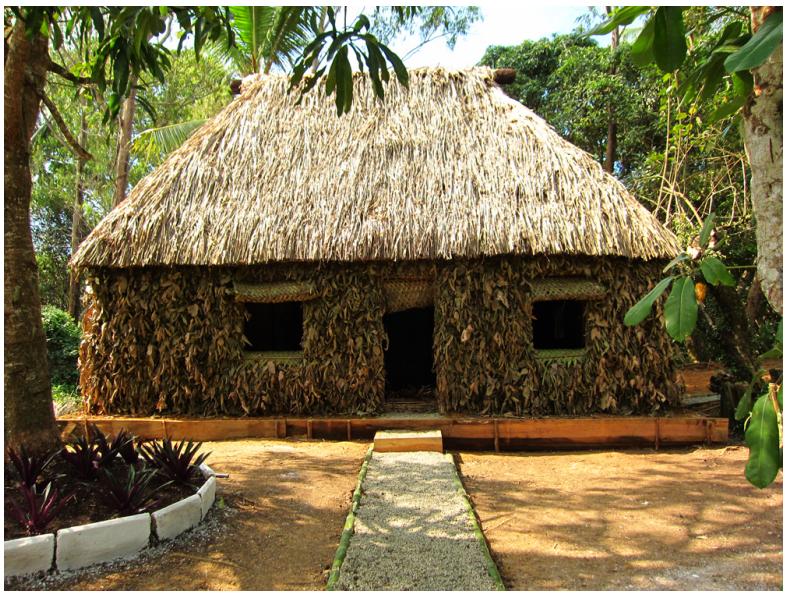

Note) Photo was taken after the completion of the Fijian traditional construction at CATD, Fiji on September 2011 by the author

Fig. 4. Completed Fijian traditional housing at CATD.

\subsection{Fijian Traditional Housing: Physical Feature 5.2.1. Forms}

The constructed Fijian traditional housing is oblong without main post type with $7.3 \mathrm{~m}(24 \mathrm{ft})$ in length and $5.48 \mathrm{~m}(18 \mathrm{ft})$. The CATD only specified the location and size to be 24 feet in length and 18 feet width. The detail of the size, forms, materials are shown in Figs. 3 and $\mathbf{4}$, and Table 2. 
Table 2. The list of parts and materials.

\begin{tabular}{|c|c|c|}
\hline \multirow{2}{*}{ Parts } & \multicolumn{2}{|l|}{ Materials } \\
\hline & Fijian & scientific name \\
\hline Posts $($ duru $)$ & $\begin{array}{l}\text { sagale } \\
\text { selala }\end{array}$ & $\begin{array}{l}\text { Lumnitzera littorea } \\
\text { Rhizophora x selala }\end{array}$ \\
\hline Wall pole (latu) & selala & Rhizophora x selala \\
\hline $\begin{array}{l}\text { King post / main pillar (bou } \\
\text { toka) }\end{array}$ & selala & Rhizophora x selala \\
\hline $\begin{array}{l}\text { Wall plate / upper plate } \\
\text { (kau tabu) }\end{array}$ & selala & Rhizophora x selala \\
\hline $\begin{array}{l}\text { Cross beam / tie beam }(i \\
\text { coka) }\end{array}$ & selala & Rhizophora x selala \\
\hline Collar beam $(i v u a)$ & selala & Rhizophora x selala \\
\hline Brace (i leqe) & selala & Rhizophora x selala \\
\hline Ridge pole $($ doka $)$ & selala & Rhizophora x selala \\
\hline $\begin{array}{l}\text { Upper ridge pole (qasiqai } \\
\text { ni kalovo) }\end{array}$ & selala & Rhizophora x selala \\
\hline Rafter (kaco) & selala & Rhizophora x selala \\
\hline Upper purlin (i cavai) & selala & Rhizophora x selala \\
\hline Middle purline (bolo) & selala & Rhizophora x selala \\
\hline Lower purlin (vavau) & selala & Rhizophora x selala \\
\hline $\begin{array}{l}\text { First layer of roofing mate- } \\
\text { rial (gasau i doka) }\end{array}$ & gausau & Eulalia japonica \\
\hline $\begin{array}{l}\text { Smaller pieces over rafters } \\
\text { to hang thatching material } \\
(\text { qavi) }\end{array}$ & tiriwai & Rhizophora mangle \\
\hline Thatching material (drau) & misimisi & $\begin{array}{l}\text { Collospermum mon- } \\
\text { tanum }\end{array}$ \\
\hline $\begin{array}{l}\text { Ridge pole ornament (so- } \\
\text { takalu) }\end{array}$ & balabla & Cyathea lunulata \\
\hline Wall-first layer & gasau & Eulalia japonica \\
\hline Wall-second layer & gasau & Eulalia japonica \\
\hline Outside material & makita & Parinarium laurinum \\
\hline $\begin{array}{l}\text { Tiring material ( } i \text { tui) } \\
\text { (between structural parts) }\end{array}$ & midri & Stenochlaena palustris \\
\hline $\begin{array}{l}\text { Tiring material }(i \text { tui }) \\
\text { (plaited wall to wall pole) }\end{array}$ & \begin{tabular}{|l} 
midri \\
vau
\end{tabular} & $\begin{array}{l}\text { Stenochlaena palustris } \\
\text { Hibiscus tricupis }\end{array}$ \\
\hline Windows and doors (leaf) & піи & Cocos nucifera \\
\hline Floor mat (ibe) & voivoi & Pandanus thurstonii \\
\hline
\end{tabular}

Note) The names of the parts and materials were obtained from interview by the authors. The scientific name in reference to [26-28]

\subsubsection{Construction Steps}

Construction started with placing corner posts called duru. Ends of posts were made concave for placing wallplates called kau tabu and cross beams called $i$ coka, which were nailed to posts. "King" posts called bou toka were placed on top of cross beams, then ridge poles called doka were laid on king posts. Rafters called kaco were placed across ridge poles and wall-plates were nailed to them. Joints were fastened by midri followed by purlins called $i$ cavai, bolo, or vavau. Color beams called $i$ vua, braces called $i$ leqe, upper ridge poles called qasiqai $n i$ kalovo, and supplementary wall posts called latu were placed and nailed down.

The roof had two layers. The first layer was made of

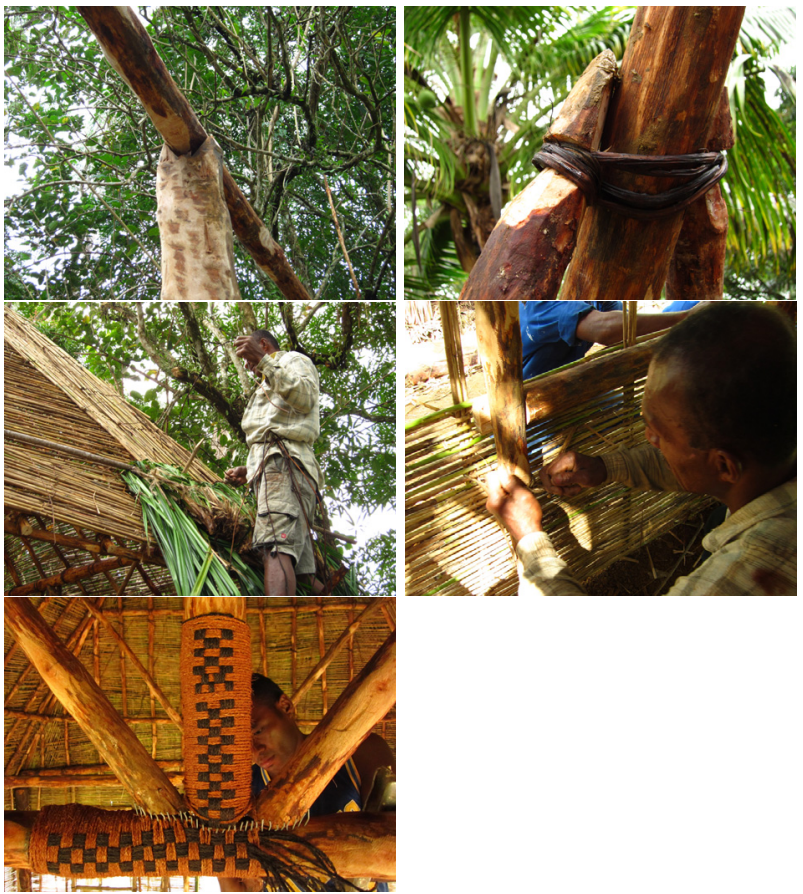

Note) Photos was taken during the Fijian traditional construction at CATD, Fiji on August 2011 by Takahiro Kanai

Fig. 5. Joint parts (top left and right), thatching (middle left), wall (middle right), and pole ornament (bottom left).

plaited gasau and tied to rafters and purlins by midri. The second layer was thatched with misimisi. A long stick of tiriwai is placed on the plaited gasau and fastened to rafters by midri, and a bundle of misimisi was hung and placed using a vula shaped like a needle. This process was mainly done by the master carpenter. Balabala were placed at each end of ridge poles. Upper ridge poles were covered with plaited coconut and misimisi.

The first layer of walls was made with gasau, sticks of which were placed horizontally between posts, then placed vertically, to alternate between them. Gasau with leaves were placed outside as the second layer, followed by makita leaves. Inside of the building was smoked at the end in order to remove insects.

\subsection{Factors to Carry out Fijian Traditional Hous- ing Construction}

\subsubsection{Knowledge and Skills}

In order to construct students in Fijian traditional housing at the CATD, it was necessary to select a master carpenter who had the knowledge and skills. A 55-year-old man from Cautata was selected. According to his interview, he learned how to construct housing while he assisted his father, who used to construct Fijian traditional housing for his village in Cautata until 30 years ago. Prior to the project, he recently built a small Fijian traditional housing as his second house in 2005.

CATD only specified the size of the building; and the master carpenter decided the forms, methods, and materials to be used. During the material collection, he gave the 
direction on the types of plants, the size and amount, and the ways to prepare as construction materials. He supervised the construction process and displayed techniques such as the ways to form the joints, to thatch, and to make walls (Fig. 5).

Although it required a master carpenter who had the knowledge and skills to lead construction, it did not require a group of highly skilled carpenters to construct housing. The master carpenter showed examples of how to treat materials and how to apply techniques, so the other eight people, who had had little experience in traditional housing construction, were able to take full part in construction. The only worker invited from outside was a person with the specific skills needed to make pole decorations with coconut fiber rope called magimagi.

\subsubsection{Workforce}

In order to construct the $7.3 \mathrm{~m}(24 \mathrm{ft}) \times 5.48 \mathrm{~m}(18 \mathrm{ft})$ Fijian traditional housing, it took two weeks for the material collection and four weeks for the construction with nine men including the master carpenter from age of twenty five to fifty five in addition to students' occasional participation in the construction. The material collection from the local forest and grassland and construction by hand required time, physically demanding works, and collaborative efforts.

The eight men are from Catutata, and mostly belong to same mataqali as the master carpenter. During the construction period, the master carpenter's wife and daughters came to CATD and prepared meals on site every day. According to him, Fijian traditional housing construction was always carried out by the collective work of village people. He explained as 'it began with a person or people who wished to construct a new one or to re-thatch the roof conveying the request to the chief who was in charge of organizing village meetings to discuss whether the construction was necessary. Once the village people agreed, they decided who involved and what tasks each had as communal work [24].' Collective work of local people carries out Fijian traditional housing construction.

\subsubsection{Equipment and Tools}

Most material collection, excluding transportation, and construction was done manually. The tools used was an axe called matau and a knife called $i$ sele and used to cut and treat construction materials, shovels used to dig holes for poles, and measuring tape, which could be replaced by body module. One tool called vula was made from a tree branch and used to saw thatch.

\subsubsection{Natural Resources}

Eleven types of plants were used for the Fijian traditional housing construction at CATD (Table 2). They included three kinds of mangroves, segala and selala for structural materials, roots of tiriwai for thatching; a type of reed, gasau, for roofing and walls; misimisi for thatching; a type of vine, midri, and bark of hibiscus tree, vau,

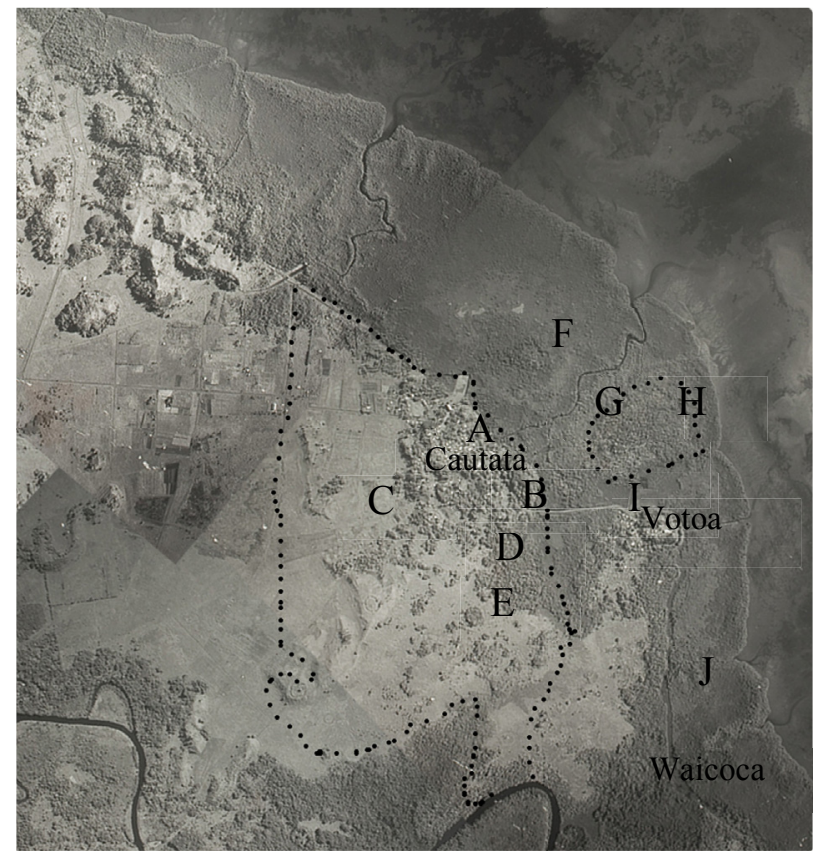

$\mathrm{K}$ : near CATD not in the map. The land is owned by Mataqali from Bau that is close to the carpenter.

$\begin{array}{ll}\text { sagale: } \mathrm{F}, \mathrm{H} & \text { selala: } \mathrm{F}, \mathrm{H}, \mathrm{J} \\ \text { tiriwai: } \mathrm{G} & \\ \text { gasau: } \mathrm{C}, \mathrm{K} & \text { misimisi: } \mathrm{A}, \mathrm{H}, \mathrm{I} \\ \text { balabla: } \mathrm{K} & \text { makita: } \mathrm{E} \\ \text { midri: } \mathrm{B}, \mathrm{D} & \text { vau: } \mathrm{F} \\ \text { niu: } \mathrm{K} & \text { voivoi }: \mathrm{F}\end{array}$

Fig. 6. Locations for material collection.

for the tying materials; a bared root of a fern; balabala, for ridge pole ornament; makita leaves for outer walls; coconut (niu) leaves for doors and windows; and voivoi for the mat.

Materials used for construction were locally available natural resources, except for nails. These materials were collected from village land where yavusa is the owning unit and the land was surrounded by mangroves (A to $\mathrm{H}$ in Fig. 6). The rest was collected from the nearby villages of Vatoa (I), Waicoca (J), and land around the CATD (K) out of convenience. In order to collect materials from the land owned by others, the master carpenter and his son made requests to owners of the land in a customary way.

\subsubsection{Summary}

The field study shows that a Fijian traditional housing is constructed manually. It does not require any special tools brought from outside. Techniques applied to the construction are rather simple; and skills can be acquired from the experience. It can be said that Fijian traditional housing construction is self-build housing that mobilize local human and local resources. The following section analyzes availability of such resources in present day. 


\section{Analysis of Available Resources for Fijian Traditional Housing in Present Day}

\subsection{Knowledge and Skills}

According to master carpenter, people began to construct a new style of housing with corrugated iron, wooden panel, and concrete in Cautata in 1950s [24]. Situation was similar in any villages in Fiji. According to the interview, the master carpenter obtained his knowledge and skills through experience when he used to assist his father who constructed a number of Fijian traditional housings for his village people in Cautata at a young age [24]. Although Fijian traditional housing is hardly constructed today, there are still elderlies who had knowledge and skills based on their past experience. However, the fact that only elderlies hold knowledge and skills suggests that sooner or later they will be disappear from the villages.

Like other indigenous knowledge, knowledge and skills associated with the Fijian traditional housings are hardly documented, stored in the memories and activities and transferred through oral communication and practical experience [8]. The master carpenter had learnt knowledge and skills by helping his father. Navala is one place where the people claim that both young and old have the knowledge and skills. Because all the people still live in the Fijian traditional housings in Navala, they carry out the construct on a regular basis and have passed down the knowledge and skills to the younger generations.

Fijian traditional housing construction project also shows that participation in actual construction is a way to teach and learn the knowledge and skills. It also teach younger generations who have not experience of Fijian traditional housing construction that it can be built easily with locally available resources and give confidence to build by their own. It was observed that a son of master carpenter who closely worked with his father took an initiative to construct a Fijian traditional housing in his village after completion of the project.

\subsection{Workforce}

Traditionally, Fijian housing construction was carried by communal work of village people. One of the eight men who participated in the project expressed that a trusting relationship and solidarity among members of his family (itokatoka), clan (mataqali) and village (or yavusa) in everyday living brought them together to carry out the tasks (I. K. Ratulo, personal communication, September 27, 2011). While a Fijian traditional housing construction requires a good deal of time and collective effort, custom and tradition of communalism, mutual help and kinship relationship still promotes contribution of people from the social group.

Beside the Fijian traditional housing construction, communal work is widely practiced in the villages in present day. Each village has their own plan of communal work managed by turaga-ni-koro (village leader) to maintain and improve the living conditions of the village. All the members who stay in a village are obligated to participate in regular communal work mostly held weekly or bi-weekly. In addition, there are several community organizations such as youth group, women's group, church committee, or school committee that people take a part in for the particular purpose in each village. Heavy involvement in preparation and participation in the ceremonies like funerals and weddings are also common. It can be said that communalism is still a big part of life in Fijian village.

\subsection{Natural Resources}

Materials used for the Fijian traditional housings are obtained in and nearby villages. People often claim that natural resources necessary for Fijian traditional housing are still available in their village. The carpenter and fellow members have an extensive knowledge in their land and know exactly which plants are found in where based on their agriculture and fishing based everyday living.

In Fiji, about 83 percent of the land belongs to indigenous Fijians and each piece of land is registered to mataqali (clan) with a few exceptions where it is owned by other social unit such as yavusa (tribe). When an indigenous Fijian is born, the baby is registered to the Native Land Register as a member of his or her father's mataqali which means that he has entitle to a particular piece of land as well as responsibility on how to use the land and associated natural resources such as plants, animals and water [25]. Their idea of land can be explained by concept of vanua which deeply embedded in the indigenous Fijian culture [22]. According to Ravuvu, vanua (literally referred as land) includes not only physical dimensions but also the social and cultural system such as practices, traditions, customs, beliefs, and values associated with the land for the sake of achieving harmony, solidary and prosperity of vanua.

\section{Conclusion}

While the Fiji is a small island country located in an area prone to natural disasters, the people in the rural areas are suffered from the reoccurring cyclones. One of the significant damages that cyclones cause is destruction of housings due to its structural vulnerability. Housing reconstruction is one of major challenges. This paper assumed self-build method with local available resources is an alternative way for housing recovery other than provision of housing through housing reconstruction program which takes time also has created dependency.

This paper focuses on traditional housing which is considered to be developed within the local context over years and examined Fijian traditional housing construction based on actual construction whether it is constructed with local human and natural resources in self-built way based on a case study of Fijian traditional housing construction project. It confirms that Fijian traditional housing is constructed with simple technologies, a few locally available equipment, and human and natural resources. 
In order to promote Fijian traditional housing as an alternative solution for housing recovery, resources, both human and natural, needs to be available in rural village in present day. There are a number of elderlies who had practical experience, knowledge and skills at young age, though they are also at risk of disappearing from villages. The construction project confirm that knowledge and skills are transferred through experience and involvement in actual construct offered opportunities for younger generations to learn skills and technologies, and to realize that it can be easily built, and gave them confidence that they can also construct. Labors and natural resources are also available within village based on custom, tradition, values which are still observed in Fijian culture and in Fijian villages today.

Some studies on indigenous knowledge raises the controversial issued of de-contextualization of indigenous knowledge and points out that efforts of archiving, transferring and institutionalizing knowledge, seems to separate it from the context despite the wide recognition of uniqueness and contextual-dependent nature of the knowledge $[8,10,12]$. As Fijian traditional housing is deeply relates to Fijian culture, and to the local context, it should be recognized that knowledge and skills can be only inherit through experience within its context. Such as Fijian traditional construction project takes a part in promoting younger generations to recognize its value and to provide incentive to learn, the remaining learning experience can obtained from elderlies in their own villages.

As Fijian traditional housing has characteristics to promote self-build housing recovery in affected area potential needs to be recognized especially by Fijian's younger generations who are the only one to inherit knowledge, skills, and culture. It assures that having knowledge and skills of Fijian traditional housing construction have an option of construction of own housing and it becomes a way to enhance capacity of people to cope with natural disasters.

\section{Acknowledgements}

This work was supported by JSPS Grant-in-Aid for Young Scientists (B) Grant Number 24710289 and Grant-in-Aid for Scientific Research (C) 24560782 and Grant-in-Aid for the Global COE Program "Sustainability/Survivability Science for a Resilient Society Adaptable to Extreme Weather Conditions" from the Ministry of Education, Culture, Sports, Science and Technology (MEXT) of Japan.

\section{References:}

[1] N. Mimura, L. Nurse, R. F. McLean, J. Agard, L. Briguglio, P. Lefale, R. Payet and G. Sem, "Small islands. Climate Change 2007: Impacts, Adaptation and Vulnerability," Contribution of Working Group II to the Fourth Assessment Report of the Intergovernmental Panel on Climate Change, M. L. Parry, O. F. Canziani, J. P. Palutikof, P. J. van der Linden and C. E. Hanson (Eds.), Cambridge University Press, Cambridge, UK, pp. 687-716.J.R., 2007.

[2] M. Pelling and J. I. Utitto, "Small island developing states: natural disaster vulnerability and global change," Environmental Hazards, Vol.3, pp. 49-62, 2001.

[3] S. Manyena, "The concept of resilience revisited," Disasters, Vol.30, No.4, pp. 433-450, 2006.
[4] J. Campbell, "Traditional Disaster Reduction in Pacific Island Communities," GNS Science Report, Vol.38, 2006.

[5] J. Veitayaki and L. Sivo, "Using Traditional Knoledge to address Climate Change: The Fiji Scenario" in Indigenous People and Conservation: From Rights to Resource Management, Conservation International, pp. 235-246, 2010.

[6] J. Mercer, D. Dominey-Howes, I. Kelman and K. Lloyd, "The potential for combining indigenous and western knowledge in reducing vulnerability to environmental hazards in small island developing states," Environmental Hazards, Vol.7, pp. 245-256, 2007.

[7] R. Chambers, "Rural Development: putting the last first," Longman, 1983.

[8] P. Sillitoe, "The development of Indigenous Knowledge: A New Applied Anthropology," Current Anthropology, Vol.39, No.2, pp. 223-252, 1998.

[9] T. W. Purcell, "Indigenous Knowledge and Applied Anthropology; Questions of Definition and Direction," Human Organization, Vol.57, No.3, pp. 258-272, 1998.

[10] A. Agrawal, "Dismantling the divide between indigenous and scientific knowledge," Development and Change, 26, pp. 413-439, 1995

[11] F. Mazzocchi, "Western science and traditional knowledge," EMBO reports," Vol.7, No.5, pp. 463-466, 2006.

[12] J. Briggs, "The use of indigenous knowledge in development: problems and challenges," Progress in Development Studies, Vol.2, pp. 99-114, 2005.

[13] Fiji Islands Bureau of Statistics, "Fiji Facts and Figures As At $1^{\text {st }}$ July 2010," Fiji Islands Bureaus of Statistics, Suva, 2010.

[14] G. K. Roth, "Fijian Way of Life second edition," Oxford University Press, Melbourne, 1973.

[15] National Disaster Management Office (NDMO), "Tropical "Cyclone Tomas" Report $12^{\text {th }}-16^{\text {th }}$ March 2010," National Disaster Management Office, Suva, 2010.

[16] C. Walsh, "Fiji: An Encyclopedia Atlas," Suva: The University of the South Pacific, 2006.

[17] P. Dubuli, Interviewee, Personal interview, March 25, 2010 (interview).

[18] UNDRO, "Shelter after Disaster Guidelines for Assistance," United Nations, New York, 1982.

[19] A. Rapoport, House, Form and Culture, Englewood Cliffs, NJ: Printice-Hall, 1969.

[20] S. Freeman, "The Centre-Poled Houses of Western Viti Levu," DOMODOMDO Fijian Museum Quartery, Vol.IV, No.V, pp. 2-19, 1986.

[21] Tippet, "Fijian Material Culture: A Study of Cultural Context, Function and Change," Bishop Museum Press, Honolulu, 1968.

[22] A. Ravuvu, "Development or Dependence," Suva: University of the South Pacific, 1988.

[23] S. Barakat, "Housing reconstruction after conflict and disaster," Humanitarian Practice Network, London, 2003.

[24] S. Tawake, Personal interview with Sermaia Tawake on March, 2012, 2011.

[25] J. Bola, Interviewee, Personal Interview, November 17, 2009 (interview).

[26] National Disaster Management Office, "Report on Tropical Cyclone Ami," National Disaster Management Office, Suva, 2003.

[27] National Disaster Management Office, "Report on February/March/April 2007 Flood and tropical Cyclone Cliff: Northern, Easter and Western Division," National Disaster Management Office, Suva, 2007.

[28] National Disaster Management Office, "Tropical Cyclone Daman, December 2007, Impact on Cikobia Island and Proposed Relief and Rehabilitation Programme," National Disaster Management Office, Suva.

[29] National Taskforce Cyclone Gene, "Tropical Cyclone Gene National Taskforce Report," National Disaster Management Office, Suva, 2008.

[30] National Disaster Management Office, "Tropical Cyclone "Mick" Report $13^{\text {th }}-16^{\text {th }}$ December 2009," National Disaster Management Office (NDMO), Suva, 2009. 
Fujieda, A. and Kobayashi, $\mathrm{H}$.

Name:

Ayako Fujieda

\section{Affiliation:}

Assistant Professor, Graduate School of Global

Environmental Studies, Kyoto University

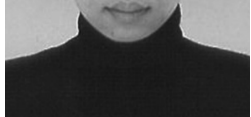

Address:

Yoshida-Honmachi, Sakyo-ku, Kyoto 606-8501, Japan

Brief Career:

2005-2008 United Nations Centre for Regional Development, Disaster

Management Planning Hyogo Office

2010- Graduate School of Global Environmental Studies, Kyoto University

Academic Societies \& Scientific Organizations:

- The Japan Society for International Development

- Architecture Institute of Japan

- Japan Institute for Pacific Studies

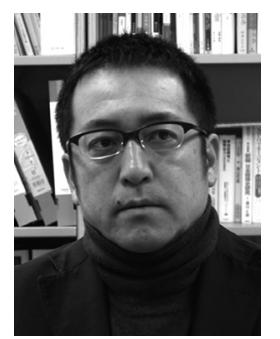

Name:

Hirohide Kobayashi

\section{Affiliation:}

Associate Professor, Graduate School of Global Environmental Studies, Kyoto University

\section{Address:}

Yoshida-Honmachi, Sakyo-ku, Kyoto 606-8501, Japan

Brief Career:

1993-2001 Architect, Showa Sekkei Inc.

2002-2009 Assistant Professor, Graduate School of Global Environmental

Studies, Kyoto University

2009- Associate Professor, Graduate School of Global Environmental

Studies, Kyoto University

Academic Societies \& Scientific Organizations:

- Architecture Institute of Japan

- City Planning Institute of japan 